\title{
SOX2 and cancer: current research and its implications in the clinic
}

Kasia Weina ${ }^{1,2}$ and Jochen Utikal ${ }^{1,2^{*}}$

\begin{abstract}
SOX2 is a gene that encodes for a transcription factor belonging to the SOX gene family and contains a high-mobility group (HMG) domain, which permits highly specific DNA binding. Consequently, SOX2 functions as an activator or suppressor of gene transcription. SOX2 has been described as an essential embryonic stem cell gene and moreover, a necessary factor for induced cellular reprogramming. SOX2 research has only recently switched focus from embryogenesis and development to SOX2's function in disease. Particularly, the role of SOX2 in cancer pathogenesis has become of interest in the field. To date, studies have shown SOX2 to be amplified in various cancer types and affect cancer cell physiology via involvement in complicated cell signaling and protein-protein interactions. Recent reviews in this field have highlighted SOX2 in mammalian physiology, development and pathology. In this review, we comprehensively compile what is known to date about SOX2's involvement in cancer biology, focusing on the most recent findings in the fields of cellular signaling and cancer stem cells. Lastly, we underscore the role of SOX2 in the clinic and highlight new findings, which may provide novel clinical applications for SOX2 as a prognostic marker, indicator of metastasis, biomarker or potential therapeutic target in some cancer types.
\end{abstract}

Keywords: SOX2; Stem cell marker; Reprogramming; Cancer; Cancer stem cells; Biomarker; Prognosis

\section{Introduction}

The SOX family is a group of related transcription factors that have demonstrated their importance in developmental and stem cell biology. In 1990, pioneering research discovered the mammalian testis-determining factor and the gene was termed Sry due to its corresponding location in the sex-determining region on the Y-chromosome $[1,2]$. Sry contains a distinctive high-mobility group (HMG) domain, which permits precise DNA recognition and binding. Proteins that contain the HMG domain with amino acid similarity of $50 \%$ or higher to the HMG domain of Sry are termed SOX (abbreviation for Sry-related HMG box) proteins [3-5]. Known functions of these proteins range from regulation of embryonic development and stem cell maintenance to homeostasis in adult tissues [6].

In 1994, the SOX2 gene, one of the SOX family members, was discovered and characterized in humans [7].

\footnotetext{
* Correspondence: j.utikal@dkfz.de

'Skin Cancer Unit, German Cancer Research Center (DKFZ), Heidelberg, Germany

²Department of Dermatology, Venereology and Allergology, University Medical Center Mannheim, Ruprecht-Karls-Universität Heidelberg,

Theodor-Kutzer-Ufer 1-3, 68135 Mannheim, Germany
}

The SOX2 gene is located on chromosome 3q26.3-q27, belongs to the SOXB1 group and encodes for a protein consisting of 317 amino acids (Figure 1A) [7,8]. SOX2 is comprised of three main domains: N-terminal, HMG and transactivation domain (Figure 1B). SOX2 research thus far has heavily emphasized its crucial role in stem cell maintenance, lineage fate determinant and a necessary factor to reprogram somatic cells back towards pluripotency $[5,9,10]$. In disease, SOX2 alterations have been associated with developmental maladies, such as anophthalmia-esophageal-genital (AEG) syndrome, which occurs when there is a heterozygous mutation of SOX2 that leads to abnormal development of ectodermal and endodermal tissues [11]. Aside from developmental diseases, accruing research has strongly associated SOX2 with cancer.

Here, we consolidate SOX2's role in cancer and provide a comprehensive overview of the field, focusing on the latest research that has implicated SOX2 in cancer biology and in the clinic. SOX2 has been shown to be associated with numerous cancer types, even described in some cases

\section{里}

(c) 2014 Weina and Utikal; licensee Springer. This is an Open Access article distributed under the terms of the Creative Commons Attribution License (http://creativecommons.org/licenses/by/4.0), which permits unrestricted use, distribution, and reproduction in any medium, provided the original work is properly credited. 


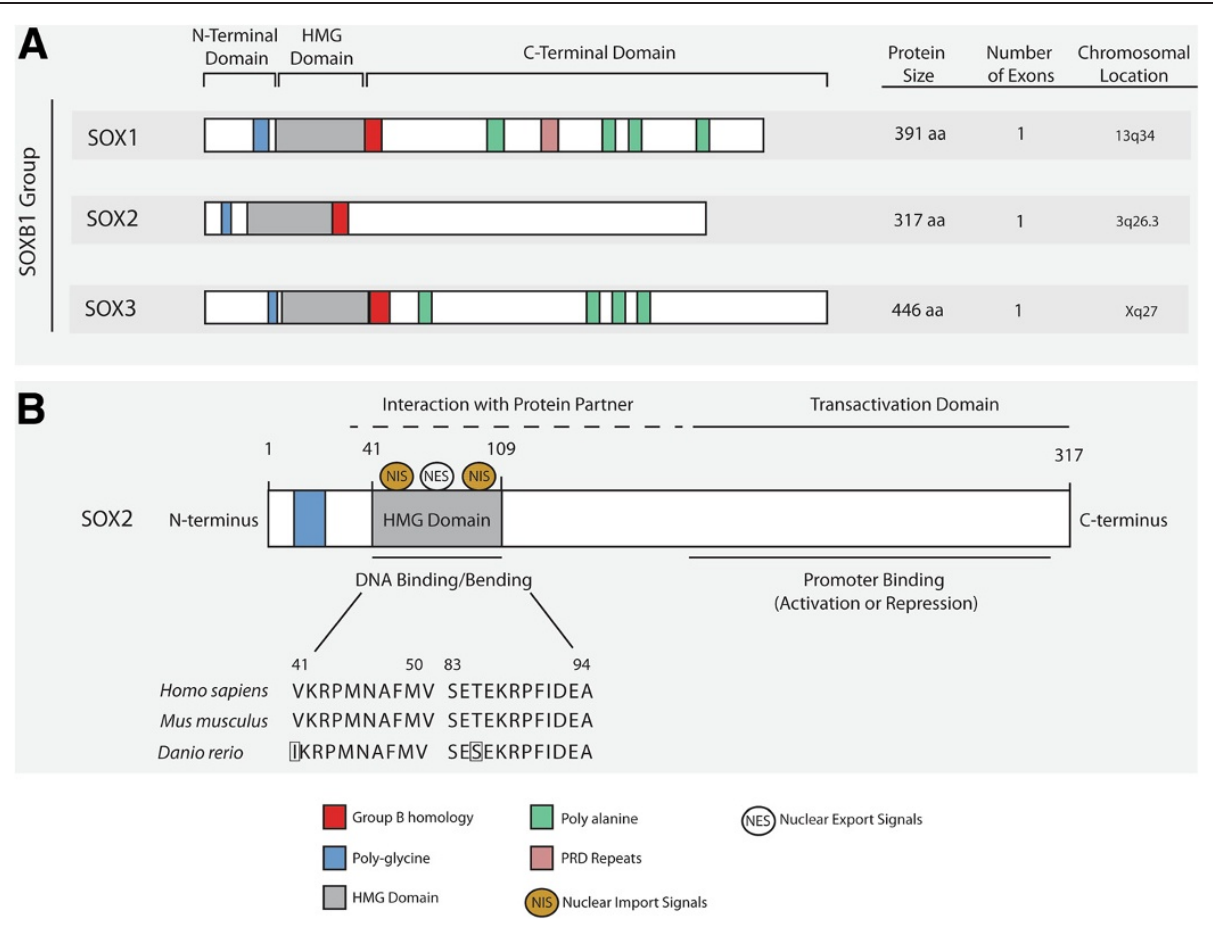

Figure 1 SOX2 homology, structure and protein function. (A) SOX2 belongs to the SOXB1 of SOX proteins. There is large homology between the SOXB1 group and they all contain three major domains: N-terminal, HMG and C-terminal domain. (B) SOX2 protein domains play several functional roles. The HMG domain of SOX2 remains fairly conserved between homo sapiens, Mus musculus and Danio rerio (Swiss-Prot: P48431, P48432, Q6P0E1). The HMG domain also serves as potential binding sites for protein partners. Moreover, nuclear import signals (NIS) and nuclear export signals (NES) bind to the HMG domain regulating SOX2 itself. Lastly the transactivation domain functions as the region responsible for promoter binding, which in turn leads to activation or repression of target genes.

as an oncogene, and controls cancer cell physiology via promoting oncogenic signaling and maintaining cancer stem cells. Lastly, we investigate recent work that has highlighted the role of SOX2 in the clinic, particularly its influence on prognosis, therapy resistance and potential therapeutic interventions.

\section{Review \\ SOX2 and cancer biology: current research SOX2 amplification in cancer}

Tumor development occurs when a cell accumulates genetic alterations that modify normal cell cycle progression. There are several means of genetic aberrations including gene deletions or gene amplification. Gene amplification is defined as a copy number increase of a particular chromosomal region. SOX2 amplification is due to multiplication of the $3 q 26.3$ gene locus $[12,13]$. SOX2 amplification has previously been found in several cancer types including glioblastoma, small-cell lung cancer (SCLC) and many forms of squamous cell carcinoma (SCC) [12,14-20]. A summary of SOX2 amplification in various cancer types with corresponding references can be found in Table 1 .
The latest SOX2 studies have focused on the coamplification of SOX2 with other critical genes. Justilien and colleagues revealed the co-amplification of two oncogenes, PRKCI and SOX2, is responsible for the cancer stem cell phenotype seen in lung squamous cell carcinoma (LSCC) [61]. Moreover, another study performed FISH analysis in 447 resected non-small cell lung cancer (NSCLC) tissue samples and SOX2 amplification was associated with increased gene copy number of FGFR1 and PI3KCA genes [62].

\section{SOX2's involvement in cancer cell physiology varies between cancer types}

As described by Hanahan and Weinberg, cancer is a disease characterized by determined hallmarks some of which are: sustained proliferative signaling, activation of invasion and metastasis, and evasion of cell death [73]. Studies have strongly associated SOX2 to these respective cancer hallmarks and thus far SOX2 has been shown to promote cellular proliferation (breast, prostate, pancreatic and cervical cancers) $[21,28,57,58]$, evade apoptotic signals (prostate, gastric cancer and NSCLC) $[37,58,63]$ and promote invasion, migration and metastasis (melanoma, colorectal, glioma, gastric, ovarian 
Table 1 Summary of SOX2 amplification and functions in cancer

\begin{tabular}{|c|c|c|c|c|}
\hline Cancer type & $\begin{array}{l}\text { SOX2 gene } \\
\text { amplification }\end{array}$ & SOX2 function & Pathway/Process & References \\
\hline Breast & No & $\begin{aligned} \uparrow \text { cell proliferation, } & \uparrow \text { colony formation, } \uparrow \downarrow \downarrow \text { invasion, } \\
& \uparrow \text { metastasis }\end{aligned}$ & $\begin{array}{c}\uparrow W N T / \beta-C A T E N I N, \uparrow E M T, \\
\downarrow A M P K / m T O R\end{array}$ & {$[21-27]$} \\
\hline Cervical & Unknown & $\uparrow c e l l$ proliferation, $\uparrow$ clonogenicity, $\uparrow$ tumorigenicity & Unknown & [28] \\
\hline Colorectal & Unknown & $\begin{array}{c}\uparrow \downarrow c e l l \text { proliferation, } \uparrow \text { metastasis, } \uparrow \text { senescence, } \uparrow \text { autophagy, } \\
\uparrow \text { tumor growth, } \uparrow \text { invasion, } \uparrow \text { migration, } \uparrow \text { anchorage- } \\
\text { dependent growth }\end{array}$ & $\begin{array}{c}\uparrow B M P, \downarrow \text { MTOR, } \uparrow M E T, \uparrow W N T / \\
\beta \text {-CATENIN }\end{array}$ & [29-33] \\
\hline Esophageal SCC & Yes & $\uparrow c e l l$ proliferation, $\uparrow$ tumor growth & $\uparrow A k t / m T O R C 1, \uparrow S T A T 3$ & {$[17,34-36]$} \\
\hline Gastric & Unknown & $\uparrow \downarrow$ apoptosis, $\uparrow \downarrow$ cell proliferation, $\uparrow$ migration & $\uparrow A K T$ signaling & {$[37-41]$} \\
\hline $\begin{array}{l}\text { Glioblastoma, GBM, } \\
\text { medulloblastoma, } \\
\text { oligodendroglioma }\end{array}$ & Yes & $\begin{array}{l}\text { 个promoter hypomethylation, } \uparrow \text { invasion, } \uparrow \text { migration, } \uparrow \text { self- } \\
\text { renewal CSCs, } \uparrow \text { cell proliferation, } \uparrow \text { colony formation }\end{array}$ & Unknown & {$[14,15,42-46]$} \\
\hline $\begin{array}{l}\text { Hepatocellular } \\
\text { carcinoma }\end{array}$ & Unknown & $\uparrow$ invasion, $\uparrow$ sphere formation & $\uparrow E M T$ & {$[47]$} \\
\hline Layngeal & Unknown & $\uparrow$ invasion/migration & $\uparrow M M P-2 \uparrow P I 3 L / A K T / m T O R$ & [48] \\
\hline Melanoma & Unknown & $\uparrow$ invasion, $\uparrow$ tumor volume, $\uparrow$ self-renewal CSCs & $\uparrow$ Hedegehog-GLI signaling & [49-53] \\
\hline Oral SCC & Yes & Unknown & Unknown & [20] \\
\hline Osteosarcoma & Unknown & $\uparrow$ self-renewal CSCs, $\uparrow$ tumorigenicity, $\uparrow$ dedifferentiation & $\downarrow W N T / \beta-C A T E N I N$ & [54] \\
\hline Ovarian & Unknown & $\uparrow$ migration, $\uparrow$ invasion, $\uparrow$ colony formation & Unknown & {$[55,56]$} \\
\hline Pancreatic & Unknown & $\uparrow c e l l$ proliferation, $\uparrow$ stemness/dedifferentiation & $\uparrow E M T$ & {$[57]$} \\
\hline Prostate & Unknown & $\begin{array}{c}\uparrow \text { self-renewal CSCs, } \uparrow \text { cell proliferation, } \uparrow \text { cell survival, } \\
\uparrow \text { metastasis, } \uparrow \text { migration, } \downarrow \text { apoptosis, } \downarrow \text { store-operated } \mathrm{Ca}^{2+} \\
\text { entry }\end{array}$ & $\begin{array}{c}\downarrow \mathrm{Ca}^{2+} \text { channels, } \uparrow \text { EMT, } \\
\downarrow \text { Survivin, } \uparrow W N T / \beta-C A T E N I N, \\
\uparrow \text { EGFR/PI3K/AKT }\end{array}$ & {$[27,58-60]$} \\
\hline $\begin{array}{l}\text { SCLC, Lung SCC, lung } \\
\text { adenocarcinoma, NSCLC }\end{array}$ & Yes & $\begin{array}{c}\uparrow c e l l \text { proliferation, } \uparrow \text { cell survival, } \downarrow \text { apoptosis, } \uparrow \text { migration, } \\
\uparrow \text { anchorage-dependent growth, } \uparrow \text { self-renewal CSCs, } \\
\uparrow \text { metastasis, } \downarrow \text { autophagy, } \uparrow \text { tumor formation }\end{array}$ & $\begin{array}{l}\uparrow M A P 4 K 4-S u r v i v i n, \downarrow \text { EGFR/ } \\
\text { Src/Akt } \downarrow \text { BMP4 }\end{array}$ & {$[12,16,19,61-70]$} \\
\hline Sinonasal & Yes & Unknown & Unknown & [71] \\
\hline $\begin{array}{l}\text { Transitional cell } \\
\text { Carcinoma }\end{array}$ & Unknown & alternative splicing & Unknown & [72] \\
\hline
\end{tabular}

SOX2 has been shown to be amplified and functionally relevant in various cancer types. SOX2 in cancer functions through multiple mechanisms that vary depending on the cancer type. However, in most cases, SOX2 has been shown to increase cell proliferation, invasion, migration, metastasis and self-renewal of CSCs. In addition, some of these phenotypes have been linked to particular oncogenic pathways, including WNT/ $\beta-C A T E N I N$, EGFR, mTOR and HH signaling. $\uparrow=$ Promotes/Improves.

$\downarrow=$ Suppresses/Inhibits.

$\uparrow \downarrow=$ Conflicting research.

cancer and hepatocellular carcinoma) [15,29,47,49,55]. We summarized SOX2 amplification and resulting alterations in cellular functions in all cancer types in Table 1 and showed examples of SOX2's role in oncogenic signaling in Figure 2. Below we highlight a few functional examples of SOX2 in cancer before we review the latest SOX2 research in different aspects of cancer physiology including: cellular proliferation, apoptosis and invasion/migration/ metastasis. For a complementary and closer examination into SOX2 and oncogenic signaling, protein-protein interactions and miRNAs see review by Liu et al. [74].

Cellular proliferation is tightly regulated by $\mathrm{SOX} 2$ in many cancer types. SOX2 knockdown in pancreatic cancer cells resulted in cell growth inhibition through cell cycle arrest, not apoptosis, via the transcriptional induction of $\mathrm{p} 21^{\mathrm{Cip} 1}$ and $\mathrm{p} 27^{\mathrm{Kip} 1}$ [57]. When SOX2 was overexpressed, cell proliferation was promoted through cyclinD3 (CCND3) transcriptional induction and allowed further S-phase entry (Figure 2B) [57]. Recently, Hütz and colleagues confirmed this in gastric cancer [37]. SOX2 was functionally inhibited via cellular transfection with a tetracycline-inducible C-terminally truncated version of SOX2, termed dnSOX2. Despite lacking the transactivation domain, dnSOX2 could bind SOX2 recognition sites on DNA and compete with wild-type SOX2. This inhibition led to the decrease in cellular proliferation in AZ-521 cells and further analysis using a RNA gene expression microarray, revealed an upregulation of $\mathrm{p} 21$ and downregulation of $\Delta \mathrm{p} 63$ (splice variant of p63) [37]. Additionally, Fang and colleagues found in LSCC, SOX2-silencing inhibited cellular proliferation via the upregulation of BMP4 [64]. After performing chromatin 


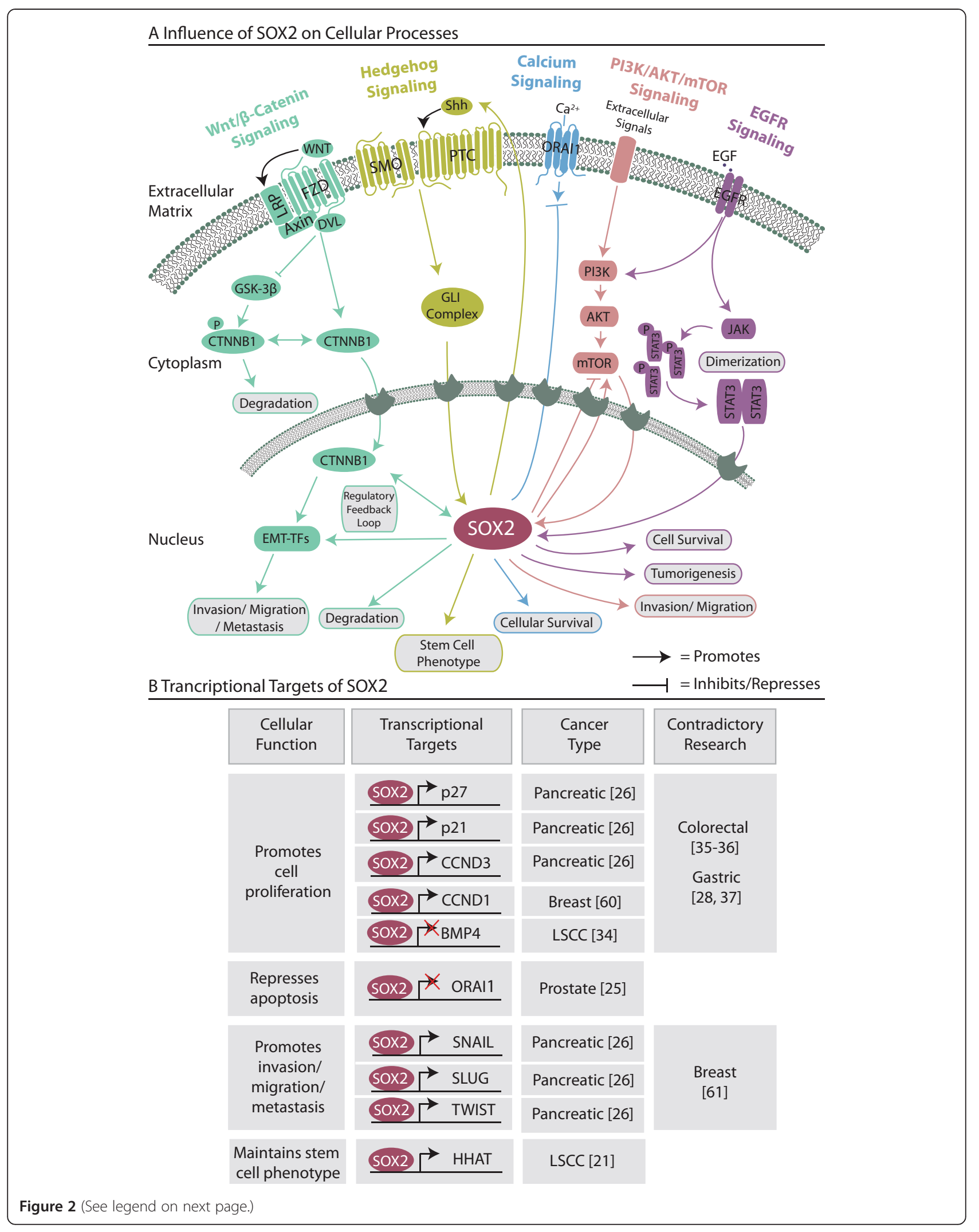


immunoprecipitation and luciferase experiments, SOX2 was found to transcriptionally repress the BMP4 promoter. The authors therefore suggest that $B M P 4$ is playing a tumor suppressor role in LSCC, while SOX2 repression of $B M P 4$ transcription causes cell growth [64]. It's important to note that the involvement of SOX2 in cell proliferation has been controversially discussed in colorectal and gastric cancer [30,31,37,38]. The contradictory effect of SOX2 in cell proliferation suggests that SOX2 plays a differential role depending on the type of cancer (Figure $2 \mathrm{~B}$ ).

SOX2 also plays an important role in evading apoptotic signals. In prostate cancer, in vitro and in vivo xenograft experiments using DU145 SOX2-overexpressing cells in NOD/SCID mice revealed that SOX2 caused an increase in apoptotic resistance by decreasing store-operated $\mathrm{Ca}^{2+}$ entry via repressing ORAI1 expression (Figure 2) [58]. Equivalently, upon silencing of SOX2 in NSCLC cell lines, apoptosis was induced [63]. Hütz and colleagues, in addition to proliferation analysis, investigated apoptosis using, caspase 3/7 assays performed in AZ-521 gastric cancer cells [37]. After 48 hours of SOX2 inhibition, nearly $60 \%$ of cells were apoptotic compared to only $20-40 \%$ of the control cells [37]. These studies prove SOX2's involvement in apoptosis inhibition and therefore in direct promotion of uncontrolled cell growth.

Finally, research has indicated that SOX2 is a novel regulator of cell invasion, migration and metastasis. For example in melanoma, SOX2 knockdown in A2058 cells resulted in a 4.5-fold decrease in invasion in vitro and adopted this phenotype via the upregulation of matrix metalloproteinase (MMP)-3 [49]. Likewise in colorectal cells, SOX2 was involved in cellular migration and invasion in vitro, but mediated these effects through MMP-2 [29]. This invasive phenotype was also confirmed in malignant glioma, since siRNA-mediated downregulation of SOX2 resulted in a significant decrease in migration and invasion capabilities [15]. Moreover SOX2 overexpression in the SOX2-negative glioma cell line U-87 resulted in a significant increase in the number of migratory and invasive cells [15]. Numerous gain and loss of function studies in several cancer types (gastric cancer, ovarian cancer and hepatocellular carcinoma) reinforced the link between SOX2 and cellular invasion and migration [15,37,47,55]. Recently, Yang and colleagues showed SOX2's involvement in promoting invasion and migration in laryngeal cancer cells through the induction of MMP-2 and the PI3K/AKT/mTOR pathway (Figure 2A) [48].

\section{SOX2 and cancer stem cells: current research}

Many tumors are derived from a single cell that has undergone malignant transformation through the acquisition of genomic aberrations, e.g. gene amplification, mutations or other mechanisms [75]. Clonal expansion of cells with tumorigenic properties is the next step towards tumor initiation. These selected cells have the ability to evade normal cell cycle checkpoints, rapidly proliferate and invade tissues [73,75]. The orchestration of tumor initiation and maintenance has been shown in some cancers to be driven by cancer stem cells (CSCs), also termed tumor-initiating cells or cancer stem-like cells. These CSCs may acquire tumor-initiating and selfrenewal properties through similar molecular mechanisms governing cellular reprogramming [76]. Evidence has linked induced cellular reprogramming to cancer and led to the assumption that CSCs may arise via a reprogramming-related mechanism [77-79]. The reactivation of stem cell-associated markers or pluripotency factors may cause dedifferentiation and a more stem cell-like state [76]. Sussman and colleagues discovered that the ubiquitin-specific protease 22 (USP22) is responsible for controlling the cellular transition from stemness towards differentiation [80]. Moreover they found USP22 represses the $S O X 2$ promoter in order to control the embryonic stem cell transition from self-renewal to differentiation [80] Therefore, not only is SOX2 an essential stem cell marker but its suppression is mandatory for cellular differentiation. For these reasons, SOX2 has been heavily investigated in CSCs in several cancer types.

\section{SOX2 regulates self-renewal and maintenance in cancer stem cell populations}

SOX2 has shown to increase CSC markers in ovarian, pancreatic, lung cancer, but research also has proven its function in self-renewal $[57,81,82]$. Self-renewal capacity of a CSC is critical and enables the maintenance of the CSC subpopulation within a tumor and SOX2 has shown to mediate this in breast, gastric, ovarian, prostate cancer, glioma, osteosarcoma, lung adenocarcinoma 
and NSCLC $[15,42,54,59,65,66,77,82,83]$. Studies in gastric cancer using siRNA-mediated SOX2 knockdown, found reduced spheroid colony formation and increased apoptosis within sphere cells, highlighting the importance of SOX2 in self-renewal capacity [83]. In prostate cancer stem cells, the activation of EGFR signaling increased SOX2 expression and the self-renewal capacity [59]. Singh and colleagues showed similar results in NSCLC, when siRNA-mediated SOX2 knockdown led to a 2.5 -fold reduction in sphere formation [65]. Moreover, EGFR/Src/ Akt signaling influenced SOX2 protein expression since during EGFR or SRC inhibition using gefitinib or BIBW, respectively, levels of SOX2 were considerably decreased [65]. Taken together, SOX2 mediates self-renewal of CSCs through EGFR signaling in at least two cancer types and is a major mediator of self-renewal in several cancers through mechanisms that remain unclear.

Recent CSC studies have concentrated on SOX2 and its mechanisms in cancer stem cell maintenance and regulation. Santini and colleagues investigated SOX2 in melanoma initiating cells and Hedgehog-GLI (HH-GLI) signaling [50]. They functionally showed that the ectopic expression of SOX2 in vitro caused enhanced self-renewal capacity in melanoma cells. Moreover, GLI1 and GLI2 downstream transcription factors of HH-GLI Signaling were able to bind to the proximal promoter of SOX2 in primary melanoma cells in chromatin immunoprecipitation (ChIP) studies and therefore SOX2 is regulated by $\mathrm{HH}$ signaling [50]. To a similar extent, Justilien and colleagues heavily investigated Hedgehog (Hh) acyltransferase (HHAT) in LSCC and found that not only are PRKCI and SOX2 coamplified and cooperate in LSCC but also SOX2 becomes phosphorylated by Protein Kinase $\mathrm{Cl}(\mathrm{PKCl})$ [61]. Next, phosphorylated SOX2 is recruited and required for HHAT expression and therefore maintenance of the stem-cell phenotype. The authors provide evidence that the coamplifcation of both oncogenes is required to activate the PKCi-SOX2HHAT signaling axis which impels the stem cell phenotype. Further work is being done on establishing $\mathrm{PKCl}$ inhibitors for LSCC treatment [61].

Lastly, a recent publication by Favaro and colleagues proved that SOX2 is required for in vitro CSC maintenance in a high-grade oligodendroglioma mouse model [43]. Oligodenrogliomas were generated in mice via the transduction of PDGF-B-IRES-GFP-encoding retrovirus within the brain at embryonic day 14.5. Additionally these embryos carried a homozygous $\mathrm{SOX} 2^{\text {flox }}$ mutation, which allowed authors to excise SOX2 using lentiviral Cre recombinase virus. Wild-type oligodendroglioma cells from mentioned mouse model were transplanted into the brain of C57/Bl6 mice, which generated lethal tumors. However, when SOX2-deletion cells were transplanted into C57/Bl6 mice they remained tumor free [43]. This elegant study proved the obligatory function of SOX2 in oligodendroglioma tumor initiation. The requirement of SOX2 in oligodendroglioma suggested possible therapeutic intervention.

\section{Correlations between SOX2 and clinical outcome: current research}

SOX2 has proven its functional role in various aspects of cancer biology. Research on SOX2 has also investigated its importance in the clinic in respect to disease prognosis, relapse, therapy resistance, comprehensive summary in Table 2 . The ability to improve reliability of diagnosis or prognosis of a cancer patient can have immense impact on survival and better understanding of the disease. For example, 162 esophageal squamous cancer patients were analyzed for SOX2 and OCT3/4 expression and high expression of both markers was associated with higher histological grade or TNM stage $(\mathrm{p}<$ 0.001 for both factors), demonstrating their link to dedifferentiation in these tumors (Table 2) [84]. Furthermore, a significant correlation between high SOX2 levels and decreasing patient survival was shown $(\mathrm{p}<0.001)$ [84]. Recently, Forghanifard and colleagues revealed that stemness state regulators SALL4 and SOX2 are overexpressed in 64 esophageal cancer samples and cooverexpression correlated with depth of tumor invasion and metastasis [85]. Again, contrasting results for SOX2's role in the clinic were highlighted in lung cancer (including NSCLC and SCLC), where SOX2 was correlated to improved survival and better patient outcome $[62,67,68,86-88]$. These opposing outcomes in the clinic further underscore the differing role of SOX2 in varying cancer types.

\section{SOX2's influence on therapy resistance}

Drug resistance has been associated with expression of various pluripotency markers, including NANOG, OCT4 and SOX2, since these genes typically lead to a decrease in differentiation status [68]. In breast cancer, silencing SOX2 not only reduced the size of the CSC population but also restored tamoxifen sensitivity, suggesting tamoxifen resistance is primarily driven by SOX2 in breast CSCs [89]. Recently, Dogan and colleagues investigated SOX2 and EGFR inhibitors in lung adenocarcinoma cell lines [68]. When a SOX2 knockdown using shRNA was performed in HCC827 cells, decreased proliferation was observed along with increased sensitivity to erlotinib. Furthermore, upon the treatment with PI3K/AKT inhibitors, SOX2 expression decreased [68]. Therefore, targeting SOX2 in EGFR-mutant tumors may be therapeutically beneficial; however more direct targeting strategies need to be further developed. 
Table 2 Clinical relevance of SOX2

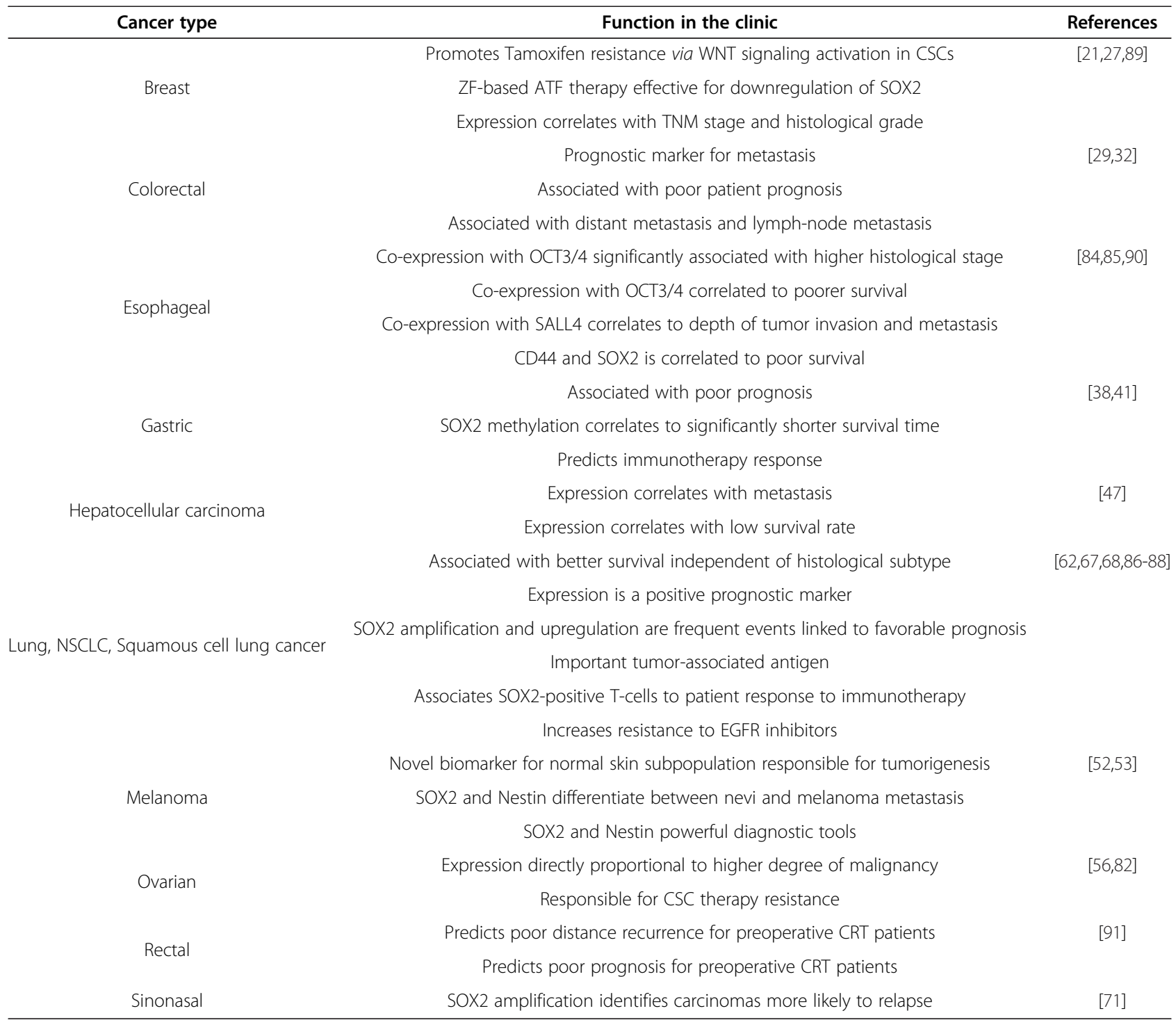

The role of SOX2 in the clinic has been studied and expression has been correlated to patient survival, prognosis and therapy. SOX2 has been shown to play different roles depending on cancer type and can predict both better and worse outcomes for patients. Moreover, SOX2 has proven its use as a prognostic marker in melanoma, colorectal, gastric and lung cancer.

\section{SOX2 and therapy options}

Improving cancer therapy options in the clinic remains a priority. SOX2 has shown its potential to become a useful biomarker in the clinic for some cancer types, for both staging tumors and identification of the CSC subpopulations (Table 2). Utilizing SOX2 for cancer therapy may open a window to new therapeutic opportunities. SOX2 does not lend itself for direct therapeutic intervention due to its importance in transcriptional cellular function and targeting SOX2 may have dozens of unwanted complications. However, targeting signals upstream or downstream of SOX2 may prove beneficial in cancer therapy. For example, as mentioned above in NSCLC and prostate CSCs, SOX2 relies heavily on EGFR signaling for mediating self- renewal in CSCs. Currently, anticancer drugs are on the market targeting EGFR, such as gefitinib and erlotinib, and may be useful in inhibiting SOX2's downstream selfrenewal effects, however resistance to these therapies is nearly inevitable and needs to be overcome. Therefore, further targeting SOX2 in EGFR-mutant cancer with PI3K/AKT inhibitors, as shown above in lung adenocarcinoma cell lines, may yield better results [68].

Recently published studies have attempted to tackle SOX2 therapy and its implications. Favaro and colleagues, who performed the oligodenroglioma studies in mice, further examined SOX2 peptides for immunotherapy treatment in mice [43]. The C57BL/6 N mice were injected with wild-type oligodendroglioma cells from established 
mouse model and upon vaccination with SOX2 peptides, significant delay in tumor growth was observed [43]. Similarly, Polakova and colleagues developed an experimental DNA vaccine against SOX2 [92]. In this study, C57BL/6 and $\mathrm{BALB} / \mathrm{c}$ mice were immunized with DNA vaccine and found a significant SOX2-specific activation of lymphocytes. However, when the antitumor effects were examined using TC-1/B7 (derived from lung cancer cell line TC-1) cells the DNA vaccination did not prevent tumor development even though it was able to significantly reduce tumor growth [92].

\section{Conclusion: SOX2 in the future}

SOX2 has proven not only to be an essential embryonic, reprogramming and development-associated gene but has begun to leave its footprint in the field of oncology. SOX2 is intricately involved in many cancer-associated processes such as cell proliferation, evading cellular apoptosis and metastasis via interactions with EGFR signaling and several other oncogenic pathways and processes. Moreover, current and ongoing SOX2 CSC research has emphasized the importance of investigating early developmental genes, since they may be responsible for selfrenewal of CSCs. Lastly, in clinical settings, SOX2 has shown a heavy influence on patient survival and prognosis. In summary, SOX2 function in cancer has been accentuated in numerous cancer types in and out of the clinic and investigating SOX2's oncogenic course is important for future prognosis, survival of cancer patients and possible therapeutic interventions.

\section{Abbreviations \\ CCND3: CyclinD3; CDH1: E-Cadherin; ChIP: Chromatin immunoprecipitation; CRT: Chemoradiotherapy; CSCs: Cancer stem cells; CTNNB1: $\beta$-Catenin; EGFR: Epidermal growth factor receptor; EMT: Epithelial-mesenchymal-transition; GBM: Glioblastoma multiforme; HH: Hedgehog; LSCC: Lung squamous cell carcinoma; mTOR: Mammalian target of rapamycin; MET: Mesenchymal- epithelial-transition; MMP: Matrix metalloproteinase; NOD/SCID: Non-obese diabetic-severe combined immunodeficiency; NSCLC: Non-small-cell lung cancer; PI3K: Phosphatidylinositol 3-kinase; PCSC: Prostate cancer stem cell; SCC: Squamous cell carcinoma; SCLC: Small-cell lung cancer; ZF-based ATF: Zinc finger-based artificial transcription factor.}

\section{Competing interests}

The authors declare that they have no commercial or other competing interests to disclose.

\section{Authors' contributions}

The author KW performed the research, writing, and revisions of the manuscript. Additionally, author KW created the figures and tables. The authors KW and JU contributed equally to the revisions of the manuscript and figures. Both authors read and approved the final manuscript.

\section{Acknowledgements}

This work was performed under the Max-Eder research grant from the German Cancer Aid. We are grateful to Janet Lei, Nathalie Schoeler and Dr. Daniel Novak for critically reading the manuscript and giving invaluable suggestions and feedback on both the text and the figures.

Received: 11 March 2014 Accepted: 6 June 2014

Published: 4 July 2014

\section{References}

1. Sinclair AH, Berta P, Palmer MS, Hawkins JR, Griffiths BL, Smith MJ, Foster JW, Frischauf AM, Lovell-Badge R, Goodfellow PN: A gene from the human sex-determining region encodes a protein with homology to a conserved DNA-binding motif. Nature 1990, 346:240-244.

2. Gubbay J, Collignon J, Koopman P, Capel B, Economou A, Muensterberg A, Vivian N, Goodfellow P, Lovell-Badge R: A gene mapping to the sexdetermining region of the mouse $\mathrm{Y}$ chromosome is a member of a novel family of embryonically expressed genes. Nature 1990, 346:245-250.

3. Guth SIE, Wegner M: Having it both ways: Sox protein function between conservation and innovation. Cell Mol Life Sci 2008, 65:3000-3018.

4. Wegner M: From head to toes: the multiple facets of Sox proteins. Nucleic Acids Res 1999, 27:1409-1420.

5. Sarkar A, Hochedlinger $\mathrm{K}$ : The sox family of transcription factors: versatile regulators of stem and progenitor cell fate. Cell Stem Cell 2013, 12:15-30.

6. Wegner M: All purpose Sox: The many roles of Sox proteins in gene expression. Int J Biochem Cell Biol 2010, 42:381-390.

7. Stevanovic M, Zuffardi O, Collignon J, Lovell-Badge R, Goodfellow P: The cDNA sequence and chromosomal location of the human SOX2 gene. Mamm Genome 1994, 5:640-642.

8. Collignon J, Sockanathan S, Hacker A, Cohen-Tannoudji M, Norris D, Rastan S, Stevanovic M, Goodfellow PN, Lovell-Badge R: A comparison of the properties of Sox-3 with Sry and two related genes, Sox-1 and Sox-2. Development 1996, 122:509-520.

9. Adameyko I, Lallemend F, Furlan A, Zinin N, Aranda S, Kitambi SS, Blanchart A, Favaro R, Nicolis S, Lübke M, Müller T, Birchmeier C, Suter U, Zaitoun I, Takahashi Y, Ernfors P: Sox2 and Mitf cross-regulatory interactions consolidate progenitor and melanocyte lineages in the cranial neural crest. Development 2012, 139:397-410.

10. Takahashi K, Yamanaka S: Induction of pluripotent stem cells from mouse embryonic and adult fibroblast cultures by defined factors. Cell 2006, 126:663-676.

11. Williamson KA, Hever AM, Rainger J, Rogers RC, Magee A, Fiedler Z, Keng WT, Sharkey FH, McGill N, Hill CJ, Schneider A, Messina M, Turnpenny PD, Rantes JA, van Heyningen V, FitzPatrick DR: Mutations in SOX2 cause anopthalmia-esophageal-genital (AEG) syndrome. Hum Mol Genet 2006, 15:1413-1422.

12. Hussenet $T$, Dali $S$, Exinger J, Monga $B$, Jost B, Dembelé $D$, Martinet $N$, Thibault C, Huelsken J, Brambilla E, du Manoir S: SOX2 is an oncogene activated by recurrent $3 q 26.3$ amplifications in human lung squamous cell carcinomas. PLoS One 2010, 5:e8960.

13. Albertson DG: Gene amplification in cancer. Trends Genet 2006, 22:447-455.

14. Annovazzi L, Mellai M, Caldera V, Valente G, Schiffer D: SOX2 expression and amplification in gliomas and glioma cell lines. Cancer Genomics Proteomics 2011, 8:139-147.

15. Alonso MM, Diez-Valle R, Manterola L, Rubio A, Liu D, Cortes-Santiago N, Urquiza L, Jauregi P, Lopez de Munain A, Sampron N, Aramburu A, TejadaSolís S, Vicente C, Odero MD, Bandrés E, García-Foncillas J, Idoate MA, Lang FF, Fueyo J, Gomez-Manzano C: Genetic and epigenetic modifications of Sox 2 contribute to the invasive phenotype of malignant gliomas. PLoS One 2011, 6:e26740

16. Hussenet T, du Manoir S: SOX2 in squamous cell carcinoma: amplifying a pleiotropic oncogene along carcinogenesis. Cell Cycle 2010, 9:1480-1486.

17. Bass AJ, Watanabe H, Mermel CH, Yu S, Perner S, Verhaak RG, Kim SY, Wardwell L, Tamayo P, Gat-Viks I, Ramos AH, Woo MS, Weir BA, Getz G, Beroukhim R, O'Kelly M, Dutt A, Rozenblatt-Rosen O, Dziunycz P, Komisarof J, Chirieac LR, Lafargue CJ, Scheble V, Wilbertz T, Ma C, Rao S, Nakagawa H, Stairs DB, Lin L, Giordano TJ, et al: SOX2 is an amplified lineage-survival oncogene in lung and esophageal squamous cell carcinomas. Nat Genet 2009, 41:1238-1242.

18. Maier S, Wilbertz T, Braun M, Scheble V, Reischl M, Mikut R, Menon R, Nikolov P, Petersen K, Beschorner C, Moch H, Kakies C, Protzel C, Bauer J, Soltermann A, Fend F, Staebler A, Lengerke C, Perner S: SOX2 amplification is a common event in squamous cell carcinomas of different organ sites. Hum Pathol 2011, 42:1078-1088.

19. Rudin CM, Durinck S, Stawiski EW, Poirier JT, Modrusan Z, Shames DS, Bergbower EA, Guan Y, Shin J, Guillory J, Rivers CS, Foo CK, Bhatt D, Stinson J, Gnad F, Haverty PM, Gentleman R, Chaudhuri S, Janakiraman V, Jaiswal BS, Parikh C, Yuan W, Zhang Z, Koeppen H, Wu TD, Stern HM, Yauch RL, Huffman KE, Paskulin DD, Illei PB, et al: Comprehensive genomic analysis 
identifies SOX2 as a frequently amplified gene in small-cell lung cancer Nat Genet 2012, 44:1111-1116.

20. Freier K, Knoepfle K, Flechtenmacher C, Pungs S, Devens F, Toedt G, Hofele C, Joos S, Lichter P, Radlwimmer B: Recurrent copy number gain of transcription factor SOX2 and corresponding high protein expression in oral squamous cell carcinoma. Genes Chromosomes Cancer 2010, 49:9-16.

21. Stolzenburg S, Rots MG, Beltran AS, Rivenbark AG, Yuan X, Qian H, Strahl BD, Blancafort P: Targeted silencing of the oncogenic transcription factor SOX2 in breast cancer. Nucleic Acids Res 2012, 40:6725-6740.

22. Lengerke $C$, Fehm $T$, Kurth $R$, Neubauer $H$, Scheble V, Müller F, Schneider $F$, Petersen K, Wallwiener D, Kanz L, Fend F, Perner S, Bareiss PM, Staebler A: Expression of the embryonic stem cell marker SOX2 in early-stage breast carcinoma. BMC Cancer 2011, 11:42.

23. Chen Y, Shi L, Zhang L, Li R, Liang J, Yu W, Sun L, Yang X, Wang Y, Zhang Y, Shang $Y$ : The molecular mechanism governing the oncogenic potential of SOX2 in breast cancer. J Biol Chem 2008, 283:17969-17978.

24. Wu F, Ye X, Wang P, Jung K, Wu C, Douglas D, Kneteman N, Bigras G, Ma Y, Lai $R$ : Sox2 suppresses the invasiveness of breast cancer cells via a mechanism that is dependent on Twist1 and the status of Sox2 transcription activity. BMC Cancer 2013, 13:317.

25. Corominas-Faja B, Cufí S, Oliveras-Ferraros C, Cuyàs E, López-Bonet E, Lupu R, Alarcón T, Vellon L, Iglesias JM, Leis O, Martín ÁG, Vazquez-Martin A, Menendez JA: Nuclear reprogramming of luminal-like breast cancer cells generates Sox2-overexpressing cancer stem-like cellular states harboring transcriptional activation of the mTOR pathway. Cell Cycle 2013, 12:3109-3124

26. Ye X, Wu F, Wu C, Wang P, Jung K, Gopal K, Ma Y, Li L, Lai R: $\beta$-Catenin, a Sox 2 binding partner, regulates the DNA binding and transcriptional activity of Sox2 in breast cancer cells. Cell Signal 2014, 26:492-501.

27. Li X, Xu Y, Chen Y, Chen S, Jia X, Sun T, Liu Y, Li X, Xiang R, Li N: SOX2 promotes tumor metastasis by stimulating epithelial-to-mesenchymal transition via regulation of WNT/ $\beta$-catenin signal network. Cancer Lett 2013, 336:379-389

28. Ji J, Zheng P-S: Expression of Sox2 in human cervical carcinogenesis. Hum Pathol 2010, 41:1438-1447.

29. Han X, Fang X, Lou X, Hua D, Ding W, Foltz G, Hood L, Yuan Y, Lin B: Silencing SOX2 induced mesenchymal-epithelial transition and its expression predicts liver and lymph node metastasis of CRC patients. PLoS One 2012, 7:e41335.

30. Fang $X$, Yu W, Li L, Shao J, Zhao N, Chen Q, Ye Z, Lin S-C, Zheng S, Lin B: ChIP-seq and functional analysis of the SOX2 gene in colorectal cancers. OMICS 2010, 14:369-384.

31. Liu H, Du L, Wen Z, Yang Y, Li J, Dong Z, Zheng G, Wang L, Zhang X, Wang C: Sex determining region $Y$-box 2 inhibits the proliferation of colorectal adenocarcinoma cells through the mTOR signaling pathway. Int J Mol Med 2013, 32:59-66.

32. Neumann J, Bahr F, Horst D, Kriegl L, Engel J, Luque RM, Gerhard M, Kirchner T, Jung A: SOX2 expression correlates with lymph-node metastases and distant spread in right-sided colon cancer. BMC Cancer 2011, 11:518.

33. Cho Y-Y, Kim DJ, Lee HS, Jeong C-H, Cho E-J, Kim M-O, Byun S, Lee K-Y, Yao K, Carper A, Langfald A, Bode AM, Dong Z: Autophagy and cellular senescence mediated by Sox2 suppress malignancy of cancer cells. PLoS One 2013, 8:e57172.

34. Gen Y, Yasui K, Nishikawa T, Yoshikawa T: SOX2 promotes tumor growth of esophageal squamous cell carcinoma through the AKT/mammalian target of rapamycin complex 1 signaling pathway. Cancer Sci 2013, 104:810-816.

35. Bass AJ, Wang TC: An inflammatory situation: SOX2 and STAT3 cooperate in squamous cell carcinoma initiation. Cell Stem Cell 2013, 12:266-268.

36. Liu K, Jiang M, Lu Y, Chen H, Sun J, Wu S, Ku W-Y, Nakagawa H, Kita Y, Natsugoe S, Peters JH, Rustgi A, Onaitis MW, Kiernan A, Chen X, Que J: Sox2 cooperates with inflammation-mediated Stat3 activation in the malignant transformation of foregut basal progenitor cells. Cell Stem Cell 2013, 12:304-315.

37. Hütz K, Mejías-Luque R, Farkasova K, Ogris M, Krebs S, Anton M, Vieth M, Schüller U, Schneider MR, Blum H, Wagner E, Jung A, Gerhard M: The stem cell factor SOX2 regulates the tumorigenic potential in human gastric cancer cells. Carcinogenesis 2014, 35(4):942-950.

38. Otsubo T, Akiyama Y, Yanagihara K, Yuasa Y: SOX2 is frequently downregulated in gastric cancers and inhibits cell growth through cell-cycle arrest and apoptosis. Br J Cancer 2008, 98:824-831.
39. Li X-L, Eishi Y, Bai Y-Q, Sakai H, Akiyama Y, Tani M, Takizawa T, Koike M, Yuasa Y: Expression of the SRY-related HMG box protein SOX2 in human gastric carcinoma. Int J Oncol 2004, 24:257-263.

40. Otsubo T, Akiyama Y, Hashimoto Y, Shimada S, Goto K, Yuasa Y: MicroRNA-126 inhibits SOX2 expression and contributes to gastric carcinogenesis. PLoS One 2011, 6:e16617.

41. Tian Y, Jia X, Wang S, Li Y, Zhao P, Cai D, Zhou Z, Wang J, Luo Y, Dong M: SOX2 oncogenes amplified and operate to activate AKT signaling in gastric cancer and predict immunotherapy responsiveness. J Cancer Res Clin Oncol 2014, 140:1117-1124.

42. Gangemi RMR, Griffero F, Marubbi D, Perera M, Capra MC, Malatesta P, Ravetti GL, Zona GL, Daga A, Corte G: SOX2 silencing in glioblastoma tumor-initiating cells causes stop of proliferation and loss of tumorigenicity. Stem Cells 2009, 27:40-48.

43. Favaro R, Appolloni I, Pellegatta S, Sanga AB, Pagella P, Gambini E, Pisati F, Ottolenghi S, Foti M, Finocchiaro G, Malatesta P, Nicolis SK: Sox2 is required to maintain cancer stem cells in a mouse model of high-grade oligodendroglioma. Cancer Res 2014, 74:1833-1844.

44. Fang X, Yoon J-G, Li L, Yu W, Shao J, Hua D, Zheng S, Hood L, Goodlett DR, Foltz $\mathrm{G}$, Lin B: The SOX2 response program in glioblastoma multiforme: an integrated ChIP-seq, expression microarray, and microRNA analysis. BMC Genomics 2011, 12:11.

45. Jeon H-M, Sohn Y-W, Oh S-Y, Oh S-Y, Kim S-H, Beck S, Kim S, Kim H: ID4 imparts chemoresistance and cancer stemness to glioma cells by derepressing miR-9*-mediated suppression of SOX2. Cancer Res 2011, 71:3410-3421.

46. Ahlfeld J, Favaro R, Pagella P, Kretzschmar HA, Nicolis S, Schüller U: Sox2 requirement in sonic hedgehog-associated medulloblastoma. Cancer Res 2013, 73:3796-3807.

47. Sun C, Sun L, Li Y, Kang X, Zhang S, Liu Y: Sox2 expression predicts poor survival of hepatocellular carcinoma patients and it promotes liver cancer cell invasion by activating Slug. Med Oncol 2013, 30:503.

48. Yang $N$, Hui $L$, Wang $Y$, Yang $H$, Jiang $X$ : SOX2 promotes the migration and invasion of laryngeal cancer cells by induction of MMP-2 via the PI3K/Akt/mTOR pathway. Oncol Rep 2014, 31:2651-2659.

49. Girouard SD, Laga AC, Mihm MC, Scolyer RA, Thompson JF, Zhan Q, Widlund HR, Lee C-W, Murphy GF: SOX2 contributes to melanoma cell invasion. Lab Invest 2012, 92:362-370.

50. Santini R, Pietrobono S, Pandolfi S, Montagnani V, D'Amico M, Penachioni JY, Vinci MC, Borgognoni L, Stecca B: SOX2 regulates self-renewal and tumorigenicity of human melanoma-initiating cells. Oncogene 2014, 1-12 [Epub ahead of print].

51. Laga A, Zhan Q, Weishaupt C, Ma J, Frank MH, Murphy GF: SOX2 and nestin expression in human melanoma: an immunohistochemical and experimental study. Exp Dermatol 2011, 20:339-345.

52. Chen P-L, Chen W-S, Li J, Lind AC, Lu D: Diagnostic utility of neural stem and progenitor cell markers nestin and SOX2 in distinguishing nodal melanocytic nevi from metastatic melanomas. Mod Pathol 2013, 26:44-53.

53. Laga AC, Lai C-Y, Zhan Q, Huang SJ, Velazquez EF, Yang Q, Hsu M-Y, Murphy GF: Expression of the embryonic stem cell transcription factor SOX 2 in human skin: relevance to melanocyte and merkel cell biology. Am J Pathol 2010, 176:903-913.

54. Basu-Roy U, Seo E, Ramanathapuram L, Rapp TB, Perry JA, Orkin SH, Mansukhani A, Basilico C: Sox2 maintains self renewal of tumor-initiating cells in osteosarcomas. Oncogene 2012, 31:2270-2282.

55. Lou X, Han X, Jin C, Tian W, Yu W, Ding D, Cheng L, Huang B, Jiang H, Lin B: SOX2 targets fibronectin 1 to promote cell migration and invasion in ovarian cancer: new molecular leads for therapeutic intervention. OMICS 2013, 17:510-518.

56. Ye F, Li Y, Hu Y, Zhou C, Hu Y, Chen H: Expression of Sox2 in human ovarian epithelial carcinoma. J Cancer Res Clin Oncol 2011, 137:131-137.

57. Herreros-Villanueva M, Zhang J-S, Koenig A, Abel EV, Smyrk TC, Bamlet WR, de Narvajas AA-M, Gomez TS, Simeone DM, Bujanda L, Billadeau DD: SOX2 promotes dedifferentiation and imparts stem cell-like features to pancreatic cancer cells. Oncogenesis 2013, 2:e61.

58. Jia X, Li X, Xu Y, Zhang S, Mou W, Liu Y, Liu Y, Lv D, Liu C-H, Tan X, Xiang R, Li N: SOX2 promotes tumorigenesis and increases the anti-apoptotic property of human prostate cancer cell. J Mol Cell Biol 2011, 3:230-238.

59. Rybak AP, Tang D: SOX2 plays a critical role in EGFR-mediated self-renewal of human prostate cancer stem-like cells. Cell Signal 2013, 25:2734-2742.

60. Lin F, Lin P, Zhao D, Chen Y, Xiao L, Qin W, Li D, Chen H, Zhao B, Zou H, Zheng $X$, Yu X: Sox2 targets cyclinE, p27 and survivin to regulate 
androgen-independent human prostate cancer cell proliferation and apoptosis. Cell Prolif 2012, 45:207-216.

61. Justilien V, Walsh MP, Ali SA, Thompson EA, Murray NR, Fields AP: The $\mathrm{PRKCl}$ and SOX2 oncogenes are coamplified and cooperate to activate Hedgehog signaling in lung squamous cell carcinoma. Cancer Cell 2014, 25:139-151.

62. Toschi L, Finocchiaro G, Nguyen TT, Skokan MC, Giordano L, Gianoncelli L, Perrino M, Siracusano L, Di Tommaso L, Infante M, Alloisio M, Roncalli M, Scorsetti M, Jänne PA, Santoro A, Varella-Garcia M: Increased SOX2 Gene Copy Number Is Associated with FGFR1 and PIK3CA Gene Gain in Non-Small Cell Lung Cancer and Predicts Improved Survival in Early Stage Disease. PLoS One 2014, 9:e95303.

63. Chen S, Li X, Lu D, Xu Y, Mou W: SOX2 regulates apoptosis through MAP4K4-Survivin signaling pathway in human lung cancer cells. Carcinogenesis 2013, 35:613-623.

64. Fang W-T, Fan C-C, Li S-M, Jang T-H, Lin H-P, Shih N-Y, Chen C-H, Wang T-Y, Huang S-F, Lee AY-L, Liu Y-L, Tsai F-Y, Huang C-T, Yang SJ, Yen L-J, Chuu C-P, Chen C-Y, Hsiung CA, Chang J-Y, Wang L-H, Chang I-S, Jiang SS: Downregulation of a putative tumor suppressor BMP4 by SOX2 promotes growth of lung squamous cell carcinoma. Int J Cancer 2014, 135(4):809-819.

65. Singh S, Trevino J, Bora-Singhal N, Coppola D, Haura E, Altiok S, Chellappan SP. EGFR/Src/Akt signaling modulates Sox2 expression and self-renewal of stem-like side-population cells in non-small cell lung cancer. Mol Cancer 2012, 11:73.

66. Xu C, Xie D, Yu S-C, Yang X-J, He L-R, Yang J, Ping Y-F, Wang B, Yang L, Xu S-L, Cui W, Wang Q-L, Fu W-J, Liu Q, Qian C, Cui Y-H, Rich JN, Kung H-F, Zhang X, Bian X-W: $\beta$-Catenin/POU5F1/SOX2 transcription factor complex mediates IGF-I receptor signaling and predicts poor prognosis in lung adenocarcinoma. Cancer Res 2013, 73:3181-3189.

67. Wilbertz T, Wagner P, Petersen K, Stiedl A-C, Scheble VJ, Maier S, Reischl M, Mikut R, Altorki NK, Moch H, Fend F, Staebler A, Bass AJ, Meyerson M, Rubin MA Soltermann A, Lengerke C, Perner S: SOX2 gene amplification and protein overexpression are associated with better outcome in squamous cell lung cancer. Mod Pathol 2011, 24:944-953.

68. Dogan I, Kawabata S, Bergbower E, Gills JJ, Ekmekci A, Wilson W, Rudin CM, Dennis PA: SOX2 expression is an early event in a murine model of EGFR mutant lung cancer and promotes proliferation of a subset of EGFR mutant lung adenocarcinoma cell lines. Lung Cancer 2014, 85(1):1-6.

69. lida H, Suzuki M, Goitsuka R, Ueno H: Hypoxia induces CD133 expression in human lung cancer cells by up-regulation of OCT3/4 and SOX2. Int J Oncol 2012, 40:71-79.

70. Chou Y-T, Lee C-C, Hsiao S-H, Lin S-E, Lin S-C, Chung C-H, Chung C-H, Kao Y-R, Wang $Y-H$, Chen C-T, Wei Y-H, Wu C-W: The emerging role of SOX2 in cell proliferation and survival and its crosstalk with oncogenic signaling in lung cancer. Stem Cells 2013, 31:2607-2619.

71. Schröck A, Göke F, Wagner P, Bode M, Franzen A, Braun M, Huss S, Agaimy A, Ihrler S, Menon R, Kirsten R, Kristiansen G, Bootz F, Lengerke C, Perner S: Sex determining region Y-box 2 (SOX2) amplification is an independent indicator of disease recurrence in sinonasal cancer. PLoS One 2013, 8:e59201.

72. Tung C-L, Hou P-H, Kao Y-L, Huang Y-W, Shen C-C, Cheng Y-H, Wu S-F, Lee M-S, Li C: SOX2 modulates alternative splicing in transitional cell carcinoma. Biochem Biophys Res Commun 2010, 393:420-425.

73. Hanahan D, Weinberg RA: Hallmarks of cancer: the next generation. Cell 2011, 144:646-674.

74. Liu K, Lin B, Zhao M, Yang X, Chen M, Gao A, Liu F, Que J, Lan X: The multiple roles for Sox 2 in stem cell maintenance and tumorigenesis. Cell Signal 2013, 25:1264-1271.

75. Bjerkvig R, Tysnes BB, Aboody KS, Najbauer J, Terzis AJA: The origin of the cancer stem cell: current controversies and new insights. Nat Rev Cancer 2005, 5:899-904.

76. Vazquez-Martin A, Cufí S, López-Bonet E, Corominas-Faja B, Cuyàs E, Vellon L, Iglesias JM, Leis O, Martín AG, Menendez JA: Reprogramming of non-genomic estrogen signaling by the stemness factor SOX2 enhances the tumorinitiating capacity of breast cancer cells. Cell Cycle 2013, 12:3471-3477.

77. Leis O, Eguiara A, Lopez-Arribillaga E, Alberdi MJ, Hernandez-Garcia S, Elorriaga K, Pandiella A, Rezola R, Martin A: Sox2 expression in breast tumours and activation in breast cancer stem cells. Oncogene 2012, 31:1354-1365.

78. Menendez S, Camus S, Herreria A, Paramonov I, Morera LB, Collado M, Pekarik V, Maceda I, Edel M, Consiglio A, Sanchez A, Li H, Serrano M,
Belmonte JCl: Increased dosage of tumor suppressors limits the tumorigenicity of iPS cells without affecting their pluripotency. Aging Cell 2012, 11:41-50

79. Bernhardt M, Galach M, Novak D, Utikal J: Mediators of induced pluripotency and their role in cancer cells - current scientific knowledge and future perspectives. Biotechnol J 2012, 7:810-821.

80. Sussman RT, Stanek TJ, Esteso P, Gearhart JD, Knudsen KE, McMahon SB: The epigenetic modifier ubiquitin-specific protease 22 (USP22) regulates embryonic stem cell differentiation via transcriptional repression of sexdetermining region Y-box 2 (SOX2). J Biol Chem 2013, 288:24234-24246.

81. Chen S, Xu Y, Chen Y, Li X, Mou W, Wang L, Liu Y, Reisfeld RA, Xiang R, LV $D, L i N$ : SOX2 gene regulates the transcriptional network of oncogenes and affects tumorigenesis of human lung cancer cells. PLoS One 2012, 7:e36326.

82. Bareiss PM, Paczulla A, Wang H, Schairer R, Wiehr S, Kohlhofer U, Rothfuss OC, Fischer A, Perner S, Staebler A, Wallwiener D, Fend F, Fehm T, Pichler B, Kanz L, Quintanilla-Martinez L, Schulze-Osthoff K, Essmann F, Lengerke C: SOX2 expression associates with stem cell state in human ovarian carcinoma. Cancer Res 2013, 73:5544-5555.

83. Tian T, Zhang Y, Wang S, Zhou J, Xu S: Sox2 enhances the tumorigenicity and chemoresistance of cancer stem-like cells derived from gastric cancer. J Biomed Res 2012, 26:336-345.

84. Wang Q, He W, Lu C, Wang Z, Wang J, Giercksky KE, Nesland JM, Suo Z: Oct3/4 and Sox2 are significantly associated with an unfavorable clinical outcome in human esophageal squamous cell carcinoma. Anticancer Res 2009, 29:1233-1241.

85. Forghanifard MM, Ardalan Khales S, Javdani-Mallak A, Rad A, Farshchian M, Abbaszadegan MR: Stemness state regulators SALL4 and SOX2 are involved in progression and invasiveness of esophageal squamous cell carcinoma. Med Oncol 2014, 31:922.

86. Chen Y, Huang Y, Huang Y, Chen J, Wang S, Zhou J: The prognostic value of SOX2 expression in non-small cell lung cancer: a meta-analysis. PLoS One 2013, 8:e71140.

87. Velcheti V, Schalper K, Yao X, Cheng H, Kocoglu M, Dhodapkar K, Deng Y, Gettinger S, Rimm DL: High SOX2 levels predict better outcome in non-small cell lung carcinomas. PLoS One 2013, 8:e61427.

88. Dhodapkar KM, Gettinger SN, Das R, Zebroski H, Dhodapkar MV: SOX2-specific adaptive immunity and response to immunotherapy in non-small cell lung cancer. Oncoimmunology 2013, 2:e25205.

89. Piva M, Domenici G, Iriondo O, Rábano M, Simões BM, Comaills V, Barredo I, López-Ruiz JA, Zabalza I, Kypta R, Vivanco MM: Sox2 promotes tamoxifen resistance in breast cancer cells. EMBO Mol Med 2014, 6(1):66-79.

90. Honing J, Pavlov KV, Meijer C, Smit JK, Boersma-van Ek W, Karrenbeld A, Burgerhof JGM, Kruyt FA E, Plukker JTM: Loss of CD44 and SOX2 Expression is Correlated with a Poor Prognosis in Esophageal Adenocarcinoma Patients. Ann Surg Oncol 2014, [Epub ahead of print].

91. Saigusa S, Tanaka K, Toiyama Y, Yokoe T, Okugawa Y, loue Y, Miki C, Kusunoki M: Correlation of CD133, OCT4, and SOX2 in rectal cancer and their association with distant recurrence after chemoradiotherapy. Ann Surg Oncol 2009, 16:3488-3498.

92. Polakova I, Duskova M, Smahel M: Antitumor DNA vaccination against the Sox2 transcription factor. Int J Oncol 2014, 45:139-146.

doi:10.1186/2001-1326-3-19

Cite this article as: Weina and Utikal: SOX2 and cancer: current research and its implications in the clinic. Clinical and Translational Medicine 2014 3:19. 